\title{
Sealing mastics for road surfacing in Siberian regions
}

\author{
Galina Vasilovskaya ${ }^{*}$, Maria Berseneva, Nadezhda Klinduh and Irina Terekhova \\ Siberian Federal University, 660041, Krasnoyarsk, Svobodny Pr., 79, Russia
}

\begin{abstract}
This paper provides the results of the studies of polymerbitumen sealing compounds for sealing seams and cracks in asphalt concrete road. The polymers used were waste from Krasnoyarsk factories (rubber-fabric and butyl-rubber crumbs) and Tomsk factories (polyethylene waste and atactic polypropylene). Here we formulate the basic requirements for sealing compounds applied in the Siberian regions. An experiment has been carried out with the use of the planning method, we prepared the compounds and determined their basic properties, as well as plotted the isolines of the compounds' properties depending on the proportioning of mineral powder and polymer waste. Based on the analysis of the isolines and comparing the properties with the requirements, we selected the optimal compositions of the prepared sealing compounds and defined their core indicators. As a result of the research, the mastic based on butylrubber crumbs was chosen as the one meeting all the requirements by all the indicators. This paper reflects the results of the test surveys on pouring cracks in the road surface of Krasnoyarsk. The developed sealing compound has been adopted in production on the roads of Krasnoyarsk Territory.
\end{abstract}

\section{Introduction}

The Russian road builders spend over $60 \%$ of all the consumed organic binders for road maintenance and repair. In mid-life and major road repairing, they traditionally lay a 3-4 $\mathrm{cm}$ thick hot mix on an old asphalt concrete pavement. In such kind of repair, there is a significant overrun of the mix and thickening of the coats, which entails the rise of curbs, wells, etc. Besides, as a rule, a new layer of asphalt concrete does not provide a reliable adhesion to the old one. This leads to penetration of water between the layers and splitting of the upper layer into pieces under the traffic load.

Therefore, when repairing the road surface, there is a need for bitumen-mineral mastics, which can be easily poured into cracks and construction seams. Such sealing compound should be dense, water-resistant, frost-resistant, adhere well to the old asphalt concrete surface and be elastic. The conventional bituminous-mineral compounds do not meet these requirements since bitumen is neither a heat-resistant nor frost-resistant material. That is why the need to improve the properties of bitumens arises. Comprehensive surveys of the bitumen properties have been carried by V.A. Zolatorev [1-3], S.V. Popadek [4] and others. The problem of improving the quality of bitumen is currently being solved by modifying

\footnotetext{
* Corresponding author: vasgv21n@mail.ru
} 
bitumen with polymer additives. This is the way either to significantly improve the operational properties of bitumen or to obtain a new material with radically different mechanical and physical as well as chemical properties. The issues of modifying the properties of bitumens are being studied by V.A. Zolotarev [5], J. Pilat [6, 7], I. Gawel [8], V.A. Yumashev, L.M. Gokhman [9] and others [10,11,12,13,14,15]. Many researchers [16,17,18,19,20,21] study the deformative and rheological properties of bitumen mastics.

The purpose of this work was to develop compounds of polymer-bitumen sealing mastics which would be a mixture of road viscous bitumen, mineral powder and a polymer additive. Waste produced in large amounts when manufacturing of synthetic rubbers, rubber goods and polyolefin was used as a polymer additive.

\section{Methods}

The used polymeric waste was the following:

1. Crumb rubber-fabric (CRF) - waste from a Krasnoyarsk rubber goods factory.

The crumb contains $34.8 \%$ of 3-4.5 mm granules, and $37.8 \%$ are granules less than $3 \mathrm{~mm}$, the mass fraction of the loosened polyester fibres is $5.5 \%$. The crumb is formed as a result of grinding vulcanized rubber-fabric waste. The rubber is a polychloroprene based one.

2. Crumb rubber based on butyl rubber (BR) - waste from a Krasnoyarsk rubber goods factory.

3. Atactic polypropylene (APP), which is a waste of a petrochemical plant in the city of Tomsk; it is manufactured as talcum powdered plates. Atactic polypropylene is a rubberlike substance with a molecular weight of 20,000-40,000 amu, and has an amorphous structure.

4. Polyethylene waste (PE). We selected granulated waste of low-density polyethylene from the Tomsk Petrochemical Plant.

5. The mastic compounds were prepared with the use of a standard mineral powder obtained by grinding limestone from the Krasnoyarsk Cement Plant in a laboratory ball mill.

6. We used 60/90 grade construction bitumen from the Achinsk Oil Refinery as a binder in the sealing compounds.

The properties of the initial materials and polymer-bitumen compounds were determined according to the methods of the corresponding Russian National Standards. Waterresistance of the compounds was characterized by water absorption under vacuum, which was determined from changing the mass of the sample buttons, having a diameter of $50 \mathrm{~mm}$ and a height of $10 \mathrm{~mm}$, which were allowed to stand in a vacuum chamber at a negative pressure of -1 atm in water for 2.5 hours, and then another 2.5 hours in water, but at a normal pressure.

Adhesion was determined by rupturing the cement Cs, glued with the compound. The rupture stress at a tensile rate of $3 \mathrm{~mm} / \mathrm{min}$, referred to a unit area, characterized the adhesion to concrete. Adhesion of mastic to asphalt concrete will be greater than to concrete, as asphalt concrete is a more porous material and has a rough surface. Thus, the determination of the adhesion of mastic to concrete is a more stringent testing method.

When developing and studying the mastic compounds, we applied the method of the experiment factorial design for two variables. The purpose of the research was to determine the relationship between the mastic compositions and their main properties, as well as to determine the optimal compound. 


\section{Results}

Various statutory documents specify the requirements for sealing materials. These requirements, however, include a wide range of indicators of the properties of sealants for all climatic zones of Russia, and due to this fact, the properties of materials can vary widely. This paper presents only the basic requirements that have to be met by sealing mastic materials. In addition, these requirements have been prescribed for materials used in Siberia for sealing seams and cracks in road asphalt concrete surfaces. The requirements have been developed based on both the generalised literature data and an excessive experience of the authors in research, production and adoption of polymer-bitumen materials.

The service temperature of mastic sealants which are in direct contact with atmospheric air is determined by the climatic conditions of the construction area. The minimum temperatures of the compounds are characterized by minimal outdoor air temperatures. In Krasnoyarsk areas, the average minimum temperature is $-35--40{ }^{\circ} \mathrm{C}$. Under these conditions, mastics should not be in an elastobrittle state, at which thermal stresses do not have time to relax and can reach critical values. Therefore, at negative temperatures, mastics should remain elastic and plastic and follow the asphalt concrete surface all the time, thus ensuring the density of seams and cracks.

A low-temperature limit of the compounds applicability is characterized by the Fraass brittle point. The lower it is the more adverse weather conditions can be tolerated by the compound. Deformability is characterized by extensibility and elasticity properties at $25^{\circ} \mathrm{C}$ and $0{ }^{\circ} \mathrm{C}$. The higher the extensibility and elasticity at $25{ }^{\circ} \mathrm{C}$ are, and the smaller its decrease is at $0{ }^{\circ} \mathrm{C}$, the better the material being considered endures low temperatures without cracking because the difference in the deformation of the mastic and the road surface material decreases when the extensibility in a wide temperature range is good.

At high summer temperatures, mastics should be heat-resistant, i.e. preserve strength at high temperatures. It is known that solar radiation, additionally to air temperature, causes heating of external black coatings. In areas of the city of Krasnoyarsk, the mastic temperature may exceed the temperature of the air by $20-30{ }^{\circ} \mathrm{C}$ and reach $60{ }^{\circ} \mathrm{C}$ in summer. Heat resistance is characterized by a softening point found by the Ring and Ball method. The higher the temperature is, the greater the heat resistance of the material is. Besides, the softening point depends directly on the content of solid polymers in bitumen, and therefore it can serve as a criterion for determining the accuracy of proportioning and polymer and bitumen blending uniformity.

Adhesion of mastics to asphalt concrete is important. At temperature stresses exceeding the value of adhesion, mastic can peel off. Adhesion was determined by rupturing the cement Cs glued with mastic. The adhesion of mastic to asphalt concrete will be greater than to cement concrete. Mastic sealants should also prevent water from penetrating into a seam or a crack, that is why they must be water-resistant and have a negligible water absorption. Moreover, they should have good technological properties, be well poured into seams and cracks and enable mechanising the technological processes associated with their production and application.

The main requirements for mastic sealants used to fill seams and cracks in road surfaces are listed below:

1. Softening point by the Ring and Ball method, ${ }^{\circ} \mathrm{C}$, not less than: $\quad 60$

2. Water sorption, \% mas., not more than:

3. Adhesion, MPa, not less than:

4. Extensibility, $\mathrm{cm}$, not less than

at $25^{\circ} \mathrm{C}$ :

at $0{ }^{\circ} \mathrm{C}$ :

5. Elasticity, $\%$, not less than 
at $25^{\circ} \mathrm{C}$ : $\quad 4$

at $0{ }^{\circ} \mathrm{C}$ : $\quad 10$

6. The Fraas brittle point, ${ }^{\circ} \mathrm{C}$, not less than: $\quad-35$

When planning the experiment, the main parameters chosen were:

$\mathrm{Y}_{1}$ - softening point by the $\mathrm{R} \& \mathrm{Bm},{ }^{\circ} \mathrm{C} ; \quad \mathrm{y}_{5}$ - elasticity at $0{ }^{\circ} \mathrm{C}, \%$;

$\mathrm{y}_{2}$ - extensibility at $25^{\circ} \mathrm{C}, \mathrm{cm}$; $\quad \mathrm{y}_{6}-$ water sorption under vacuum, \%;

$\mathrm{y}_{3}$ - extensibility at $0^{\circ} \mathrm{C}, \mathrm{cm} ; \quad \mathrm{y}_{7}$ - adhesion, $\mathrm{MPa}$;

$\mathrm{y}_{4}$ - elasticity at $25^{\circ} \mathrm{C}, \%$; $\quad \mathrm{y}_{8}-$ The Fraas brittle point, ${ }^{\circ} \mathrm{C}$

The main impact factors were:

$\mathrm{X}_{1}-$ mineral powder proportion, $\% ; \quad \mathrm{X}_{2}$ - polymer additive proportion, $\%$.

In addition, we studied the joint effect of mineral powder and polymer additives $\mathrm{X}_{1} \mathrm{X}_{2}$ on the properties of the mastics. Bitumen was deemed as $100 \%$ in the compositions. To carry out the experiment, we compiled a design matrix where its rows corresponded to the series of tests, and the columns corresponded to the values of the factors. In the matrix, the dosage of the mineral powder varied from $10 \%$ to $60 \%$, and that of the polymer additive was from $2 \%$ to $15 \%$. The maximum content of polymer waste in the mastics was confined by the limits of technological compatibility and the cost of mastics. If the content of waste is large, we observe its poor distribution in bitumen, plus the cost of mastics increases. The experiment design matrix is given in table 1.

Table 1. The experiment design matrix

\begin{tabular}{|c|c|c|c|c|c|c|}
\hline \multirow{2}{*}{ Test No. } & \multicolumn{4}{|c|}{ Code values of the factors } & \multicolumn{2}{|c|}{ Natural values of the factors } \\
\hline & $\mathbf{X}_{\mathbf{0}}$ & $\mathbf{X}_{1}$ & $\mathbf{X}_{2}$ & $\mathbf{X}_{1} \mathbf{X}_{2}$ & $\mathbf{X}_{1}$ & $\mathbf{X}_{2}$ \\
\hline 1 & + & + & + & + & 60 & 15 \\
\hline 2 & + & - & + & - & 10 & 15 \\
\hline 3 & + & + & - & - & 60 & 2 \\
\hline 4 & + & - & - & + & 10 & 2 \\
\hline
\end{tabular}

Based on the design matrix, we conducted the experiment and determined the main properties of the mastics. The mastics were prepared in the laboratory as follows: the required amount of the polymer additive was gradually added to evaporated and heated bitumen. The temperature of blending bitumen with rubber-fabric and butyl rubber crumb was 160$180{ }^{\circ} \mathrm{C}$, the blending time was $1.5-2$ hours. The temperature of blending bitumen, atactic polypropylene and polyethylene was $140-160^{\circ} \mathrm{C}$, and the blending time was $0.5-1$ hour.

After mathematical processing of the experiment results and checking them for the respective criteria, we derived the following regression equations which were adequate subject to F-test.

For polyethylene waste:

$\begin{array}{ll}\mathrm{y}_{1}=79,37+1,12 \mathrm{X}_{1}+14,37 \mathrm{X}_{2} & \mathrm{y}_{4}=3,65+1,36 \mathrm{X}_{1}+232 \mathrm{X}_{2} \\ \mathrm{y}_{2}=15,07-7,72 \mathrm{X}_{1}-12,72 \mathrm{X}_{2}+6,77 \mathrm{X}_{1} \mathrm{X}_{2} & \mathrm{y}_{5}=8,2-3,22 \mathrm{X}_{1}+1,97 \mathrm{X}_{2}+1,1 \mathrm{X}_{1} \mathrm{X}_{2} \\ \mathrm{y}_{3}=2,49-0,69 \mathrm{X}_{1}-0,94 \mathrm{X}_{2}+0,49 \mathrm{X}_{1} \mathrm{X}_{2} & \mathrm{y}_{6}=0,06-0,008 \mathrm{X}_{1}+1,19 \mathrm{X}_{2} \\ \mathrm{y}_{8}=25,19-1,19 \mathrm{X}_{1} & \mathrm{y}_{7}=0,18-0,05 \mathrm{X}_{2}+0,045 \mathrm{X}_{1} \mathrm{X}_{2} \\ \text { For rubber-fabric crumb: } & \mathrm{y}_{4}=23,48-4,85 \mathrm{X}_{1}+9,89 \mathrm{X}_{2}+2,17 \mathrm{X}_{1} \mathrm{X}_{2} \\ \mathrm{y}_{1}=71,13+3,38 \mathrm{X}_{1}+13,38 \mathrm{X}_{2}+2,63 \mathrm{X}_{1} \mathrm{X}_{2} & \mathrm{y}_{5}=13,89-3,45 \mathrm{X}_{1} \mathrm{X}_{2}\end{array}$




$$
\begin{array}{ll}
\mathrm{y}_{2}=13,97+2,22 \mathrm{X}_{1}+2,34 \mathrm{X}_{2}+4,59 \mathrm{X}_{1} \mathrm{X}_{2} & \mathrm{y}_{6}=0,72-0,46 \mathrm{X}_{2} \\
\mathrm{y}_{3}=5,69-0,94 \mathrm{X}_{2} & \mathrm{y}_{8}=29,86+1,88 \mathrm{X}_{2} \\
\text { For atactic polypropylene: } & \frac{\text { For butyl rubber crumb: }}{\mathrm{y}_{1}=68,5+4,5 \mathrm{X}_{1}+8 \mathrm{X}_{2}} \\
\mathrm{y}_{1}=75,13+3,13 \mathrm{X}_{1}+16,13 \mathrm{X}_{2}-2,38 \mathrm{X}_{1} \mathrm{X}_{2} & \mathrm{y}_{2}=17,15+7,78 \mathrm{X} 1+13,5 \mathrm{X}_{2} \\
\mathrm{y}_{2}=6,25-2,75 \mathrm{X}_{1}-4,13 \mathrm{X}_{2}+2,38 \mathrm{X}_{1} \mathrm{X}_{2} & \mathrm{y}_{3}=3,2-013 \mathrm{X}_{1}+1,07 \mathrm{X}_{2}-0,57 \mathrm{X}_{1} \mathrm{X}_{2} \\
\mathrm{y}_{3}=3,13-1,63 \mathrm{X}_{2} & \mathrm{y}_{4}=2,19+0,805 \mathrm{X}_{1}+1,09 \mathrm{X}_{2} \\
\mathrm{y}_{4}=11,62+3,08 \mathrm{X}_{2} & \mathrm{y}_{5}=16,15+3,43 \mathrm{X}_{1}+5,69 \mathrm{X}_{2} \\
\mathrm{y}_{5}=11,65+3,7 \mathrm{X}_{2} & \mathrm{y}_{6}=0,1+0,016 \mathrm{X}_{1}-0,015 \mathrm{X}_{2} \\
\mathrm{y}_{6}=0,72-0,42 \mathrm{X}_{2} & \mathrm{y}_{7}=0,41+0,09 \mathrm{X}_{1} \\
\mathrm{y}_{7}=0,51+0,11 \mathrm{X}_{2} & \mathrm{y}_{8}=29,94+3,31 \mathrm{X}_{2}+4,19 \mathrm{X}_{1} \mathrm{X}_{2} \\
\mathrm{y}_{8}=22,69+3,56 \mathrm{X}_{2} &
\end{array}
$$

\section{Discussions}

Analyzing the obtained regression equations, we can draw the following conclusions: feeding of all the polymer additives leads to an increase of the softening point of mastics. This indicator is particularly influenced by additives of polyethylene waste, atactic polypropylene and rubber-fabric crumb.

An increase in the proportions of rubber-fabric and butyl rubber crumbs leads to an increase in elasticity at $25{ }^{\circ} \mathrm{C}$ and $0{ }^{\circ} \mathrm{C}$; but in the compounds with polyethylene waste and atactic polypropylene, as the proportions of these additives increase, elasticity decreases. When butyl rubber crumbs, waste polyethylene, atactic polypropylene are added, the compounds' elasticity grows. When adding rubber-fabric crumbs, the compounds' elasticity at 0 ${ }^{\circ} \mathrm{C}$ decreases. Adding all the polymer waste leads to a reduction in water absorption, an increase in adhesion of the compounds and a lowering of the brittle point. It is notable that the lowest brittle temperatures, corresponding to the designed requirements, turned out to be the ones of the compounds with butyl rubber crumb. Thus, based on the tests, we can conclude that only adding butyl rubber crumb results in improving all the indicators of the compounds.

The resulting regression equations were plotted. The calculations and plotting of output parameters were carried out in Mathcad software system. The graphs in Figures 1-4 are isolines of the properties of the compounds. According to these isolines, we can evaluate the joint impact on the properties of mastic made of polymer waste and mineral powder. The graphs were constructed from solutions of the equations given above. Using these equations, we found the values of the output parameters within the limits of the factors variation from +1 to -1 . Substituting the values of each factor in the specified range into the regression equations, we obtained the values of the output parameters for the corresponding intermediate values of the factors.

Analysing figure 1.a, we see that all the compounds with polyethylene waste are heatresistant, but have insufficient extensibility. The compositions containing the maximum amount of polymer (fig. 1.b) have the best elasticity, water absorption and brittle point, but their adhesion is little. Therefore, we choose point $\mathrm{E}$ as the optimal compound containing $25 \%$ of mineral powder and $6 \%$ of polymer waste.

Fig. 2.a and 2.b show that the compounds with rubber-fabric crumb, meeting the requirements for softening point, elasticity at $25{ }^{\circ} \mathrm{C}$ and $0{ }^{\circ} \mathrm{C}$, extensibility at $0{ }^{\circ} \mathrm{C}$ and water absorption, however, do not meet the requirements for elasticity at $25{ }^{\circ} \mathrm{C}$ and the brittle point. The optimal compound can be found at point $\mathrm{B}$, which contains $30 \%$ mineral powder and $8.5 \%$ rubber-fabric crumb.

Fig. 3 presents the isolines of mastic with atactic polypropylene. In figure 3.a, it is clear that all the compounds do not meet the requirements for extensibility at $25{ }^{\circ} \mathrm{C}$, but as for the softening point, we can choose the compounds with $4.5 \%$ to $5 \%$ content of atactic poly- 
propylene. Analysing fig. 3.b, we conclude that all the compounds satisfy the requirements by water absorption, adhesion to concrete and elasticity at $25^{\circ} \mathrm{C}$.

In terms of the brittle point, all the compounds do not meet the requirements; but as for their extensibility at $0{ }^{\circ} \mathrm{C}$, the compounds with a minimum content of mineral powder and atactic polypropylene satisfy the requirements. On the contrary, the compounds with the maximum polymer content meet the requirements by elasticity at $0{ }^{\circ} \mathrm{C}$. Consequently, the recommended compound for mastics with atactic polypropylene will be at point $\mathrm{B}$, where the mineral powder is $52.5 \%$, and the polymer is $7 \%$.
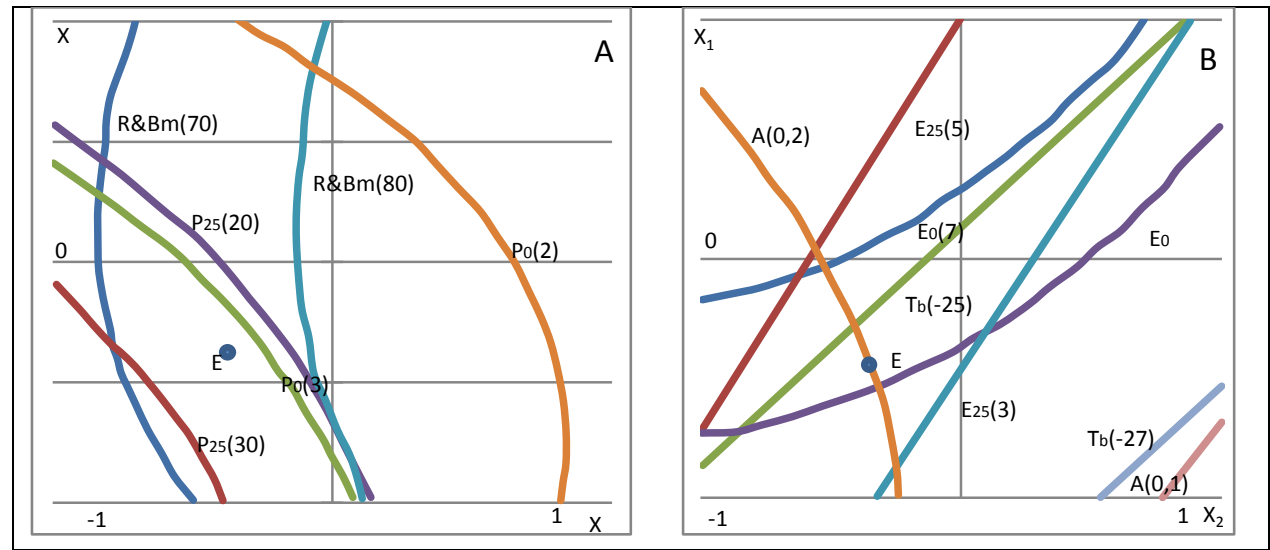

Fig. 1. The graphs of the softening point $(\mathrm{R} \& \mathrm{Bm})$, extensibility at $0{ }^{\circ} \mathrm{C}\left(\mathrm{E}_{0}\right)$, extensibility at $25^{\circ} \mathrm{C}$ $\left(\mathrm{E}_{25}\right)$, adhesion $(\mathrm{A})$, brittle point $\left(\mathrm{T}_{\mathrm{b}}\right)$ and elasticity $(\mathrm{E})$ and polymer-bitumen compounds based on polyethylene waste

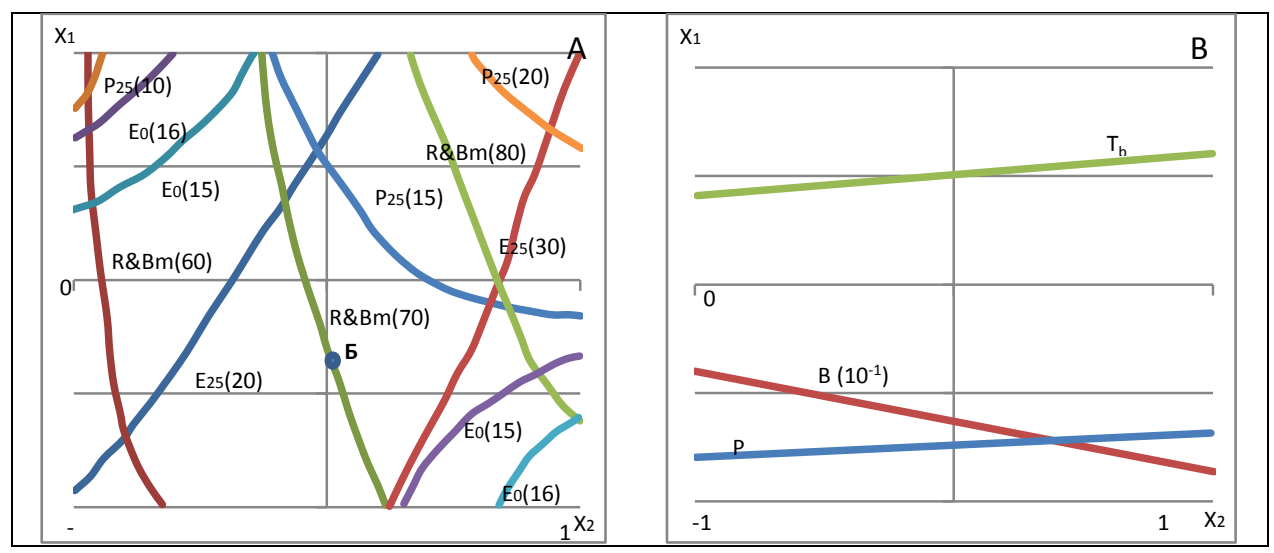

Fig. 2. The graphs of the softening point (R\&Bm), extensibility at $0{ }^{\circ} \mathrm{C}\left(\mathrm{E}_{0}\right)$, extensibility at $25^{\circ} \mathrm{C}\left(\mathrm{E}_{25}\right)$, brittle point $\left(\mathrm{T}_{\mathrm{b}}\right)$ and elasticity $(\mathrm{E})$ and polymer-bitumen compounds based on rubber-fabric crumbs 


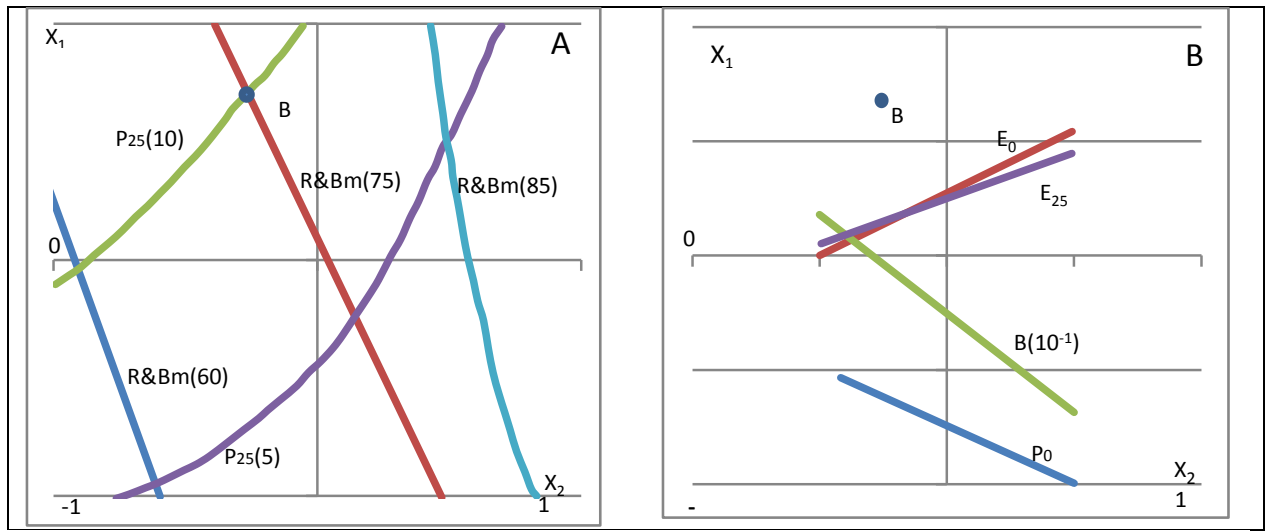

Fig. 3. The graphs of the softening point $(\mathrm{R} \& \mathrm{Bm})$, extensibility at $25^{\circ} \mathrm{C}\left(\mathrm{E}_{25}\right)$, elasticity $\left(\mathrm{E}_{0}\right)$ and polymer-bitumen compounds based on atactic polypropylene

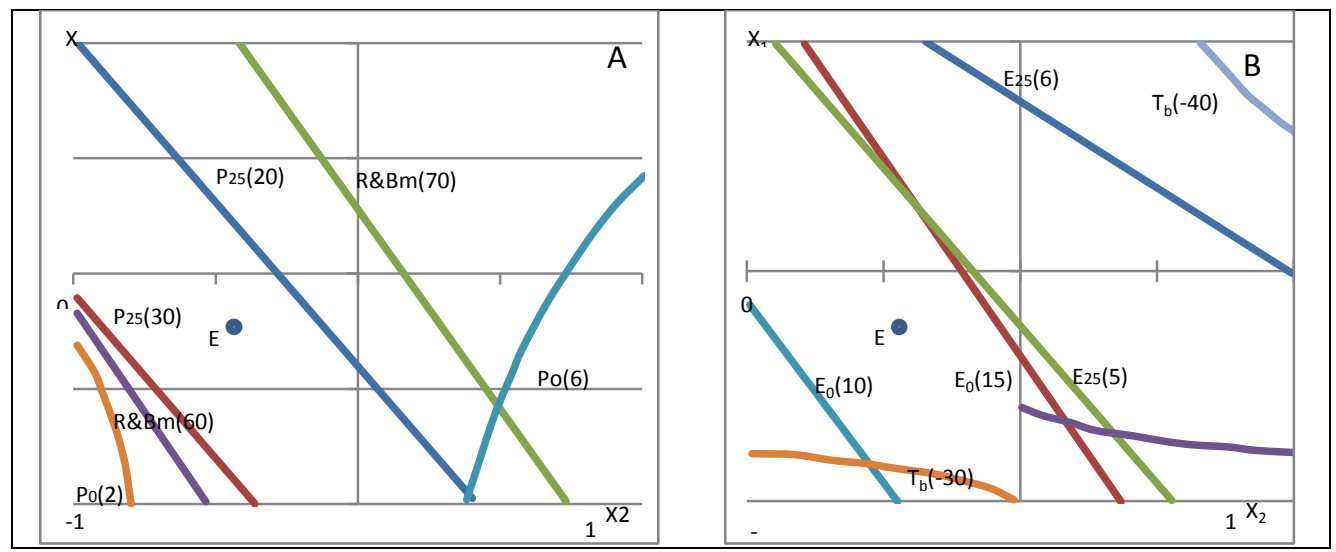

Fig. 4. The graphs of the softening point $(\mathrm{R} \& \mathrm{Bm})$, extensibility at $0{ }^{\circ} \mathrm{C}\left(\mathrm{E}_{0}\right)$, extensibility at $25^{\circ} \mathrm{C}\left(\mathrm{E}_{25}\right)$, adhesion (A), brittle point $\left(\mathrm{T}_{\mathrm{b}}\right)$ and elasticity $(\mathrm{E})$ and polymer-bitumen compounds based on butyl rubber crumb

Fig. 4.a shows that the compounds containing about $7 \%$ of butyl rubber crumbs meet the requirements for extensibility at $25{ }^{\circ} \mathrm{C}$ and $0{ }^{\circ} \mathrm{C}$ and heat resistance. The compound at point I which contains $30 \%$ mineral powder and $7 \%$ butyl rubber crumb meets the designed requirements in terms of elasticity at $25^{\circ} \mathrm{C}$ and $0{ }^{\circ} \mathrm{C}$, water absorption, adhesion and brittle point values (fig. 4.b).

Thus, on the ground of the tests carried out, we can recommend the optimal compounds of polymer-bitumen mastics, which have the following properties (table 2). Using the same indicators, we also prepared and tested a standard compound of mastic consisting of $70 \%$ limestone mineral powder and $30 \%$ bitumen. 
Table 2. The optimum compounds and properties of polymer-bitumen mastics

\begin{tabular}{|c|c|c|c|c|c|c|c|c|}
\hline \multirow[b]{2}{*}{$\begin{array}{c}\text { Compounds, } \\
\%\end{array}$} & \multirow{2}{*}{$\begin{array}{c}\text { Softening } \\
\text { point by } \\
\text { R\&Bm, } \\
{ }^{\circ} \mathbf{C}\end{array}$} & \multicolumn{2}{|c|}{$\begin{array}{c}\text { Extensibility, } \\
\text { cm }\end{array}$} & \multicolumn{2}{|c|}{ Elasticity, \% } & \multirow{2}{*}{$\begin{array}{c}\text { Water } \\
\text { absorption, } \\
\%\end{array}$} & \multirow[b]{2}{*}{$\begin{array}{c}\text { Adhesion, } \\
\text { MPa }\end{array}$} & \multirow{2}{*}{$\begin{array}{c}\text { Brittle } \\
\text { point, } \\
{ }^{\circ} \mathrm{C}\end{array}$} \\
\hline & & $\begin{array}{l}\text { at } \\
25 \\
{ }^{\circ} \mathrm{C}\end{array}$ & $\begin{array}{c}\text { at 0 } \\
{ }^{\circ} \mathbf{C}\end{array}$ & $\begin{array}{c}\text { at } \\
25^{\circ} \mathrm{C}\end{array}$ & $\begin{array}{c}\text { at } 0 \\
{ }^{\circ} \mathrm{C}\end{array}$ & & & \\
\hline $\begin{array}{l}\text { MP - } 25 \\
P E-6\end{array}$ & 76 & 24,0 & 3,1 & 4,0 & 8,4 & 0,06 & 0,20 & $-25,2$ \\
\hline $\begin{array}{l}\text { MP - 30 } \\
\text { CRF - 8,5 }\end{array}$ & 70 & 12,5 & 5,7 & 23,8 & 13,9 & 0,72 & 0,75 & $-29,9$ \\
\hline $\begin{array}{l}\text { MP - 52,5 } \\
\text { APP -7 }\end{array}$ & 75 & 10,0 & 3,5 & 10,9 & 10,8 & 0,81 & 0,48 & $-21,9$ \\
\hline $\begin{array}{l}\text { MP -30 } \\
\text { BR -7 }\end{array}$ & 66 & 20,8 & 4,0 & 4,8 & 14,1 & 0,10 & 0,39 & $-35,0$ \\
\hline $\begin{array}{l}\text { MP -70 } \\
\text { Bitumen -30 }\end{array}$ & 50 & 4,5 & 1,5 & 6,7 & 13,4 & 0,39 & 0,25 & $-20,0$ \\
\hline Required & $\begin{array}{l}\text { Not less } \\
\text { than } 60\end{array}$ & $\begin{array}{c}\text { Not } \\
\text { less } \\
\text { than } \\
20\end{array}$ & $\begin{array}{c}\text { Not } \\
\text { less } \\
\text { than } 4\end{array}$ & $\begin{array}{c}\text { Not } \\
\text { less } \\
\text { than } 4\end{array}$ & $\begin{array}{c}\text { Not } \\
\text { less } \\
\text { than } \\
10 \\
\end{array}$ & $\begin{array}{l}\text { Not more } \\
\text { than } 1\end{array}$ & $\begin{array}{l}\text { Not less } \\
\text { than } 0,2\end{array}$ & $\begin{array}{c}\text { Not } \\
\text { higher } \\
\text { than } \\
-35 \\
\end{array}$ \\
\hline
\end{tabular}

As it is seen in the table, the properties of the standard compound are much worse than the optimal compounds developed. It is also seen that among all the optimal compounds, the best properties are those of the mastic with butyl rubber crumbs. That is why this is the very mastic which was chosen for adopting in the production.

The optimal butyl rubber crumb mastic compound was adopted in the production conditions. In July and September 2017, a commission consisted of the head of the Department Road Quality for Krasnoyarsk Territory and the authors of this work experimentally tested the mastics for sealing cracks in road asphalt concrete surfaces on the "University-Sopka" road section. The development work was carried out at an external air temperature of +25 ${ }^{\circ} \mathrm{C}$ in July, and at $+8{ }^{\circ} \mathrm{C}$ in September; the cracks being sealed were 0.5 to $3 \mathrm{~cm}$ deep and 0.5 to $15 \mathrm{~cm}$ wide, and they were cleaned and dedusted before applying the compounds. The total length of the sealed cracks was $50 \mathrm{~m}$.

The tests showed that the mastics have good flowability and adhesion to asphalt concrete at a temperature of $140-160{ }^{\circ} \mathrm{C}$ in summer, and at $160-180{ }^{\circ} \mathrm{C}$ in autumn. To ensure adhesion of mastics, cracks must be dry. As a result of the development work, we found that the cracks up to $1 \mathrm{~cm}$ deep cool down to "aftertack" after 5-10 minutes, and those ones up to $3 \mathrm{~cm}$ deep require 10-15 minutes. The traffic may be permitted to the repaired road section after 20 or 30 minutes respectively. An examination after a year of operation showed the good condition of the repaired road section. After this development work, the Krasnoyarsk Territory Road Department began to adopt the developed mastic compound on the roads of Krasnoyarsk and Krasnoyarsk Territory.

\section{Conclusions}

1. Polymer waste from Siberian factories has been studied: atactic polypropylene and polyethylene waste from the Tomsk Fuel and Petrochemical Refinery, and rubber-fabric and butyl rubber crumbs which are waste from the Krasnoyarsk Rubber Goods Factory.

2. The requirements for sealing mastics for sealing seams and cracks in road asphalt surfaces have been developed.

3. We compiled an experiment design matrix using the mathematical method of experiment design. According to this matrix, we perform the experiment, prepared polymer- 
bitumen compounds, and defined their basic properties. Processing the experiment results and checking them subject to the appropriate criteria resulted in regression equations which show a dependence of the mastics properties and the proportions of the mineral powder and polymer additives. According to the obtained regression equations, we plotted the graphs which are the isolines of mastic properties within the variation of the factors. Analysing the resulting isolines and comparing the properties of the mastics with the developed requirements resulted in finding the optimal compounds of polymer-bitumen mastics.

4. It was shown that adding all the polymer additives leads to an increase in the softening point, adhesion of the compounds and to a decrease in water absorption and the brittle point. The lowest brittle points were obtained for the mastic with butyl rubber crumb. Besides, this compound meets the developed requirements for all the indicators and has good processing properties. That is why the compound of 60/90 grade construction bitumen $-100 \%, 7 \%$ butyl rubber crumb and $30 \%$ mineral powder was recommended for production adopting.

5. The development work results are shown. In 2017, we sealed cracks in the asphalt concrete road surface on a road section in the city of Krasnoyarsk using the proposed compound. The tests showed good processing properties of the compound when pouring: flowability, adhesion to the old asphalt concrete and rapid cooling. The examination of the repaired area after a one-year operation showed a good condition of this section, and after the development work, the Road Department for Krasnoyarsk Territory began to introduce the developed mastic compound on the roads of Krasnoyarsk and Krasnoyarsk Territory.

\section{References}

1. Zolotarev V.A. What bitumen is such asphalt [Zolotarev V.A. As is the bitumen so is the asphalt]. Motorways [Motorways]. 2001. No.6. P. 12-13.

2. Zolotarev V.A. The effect of temperature and group composition on the extensibility of bitumen [Zolo-tarev V.A. The effect of temperature and bitumen]. Science and technology in the road sector [Engineering and Science in the Road Sector]. 2002. No.2. Pp.1213.

3. Zolotarev V.A. On the relationship of the rheological properties of bitumen and asphalt [Zolotarev V.A. About the interrelation of the rheological properties of bitumen and asphalt concrete] Science and technology in the road industry [Engineering and Science in the Road Sector]. 2002. No.4. Pp. 3-6.

4. Popadek S.V. Once again about the quality problem in the modification of bitumens with SBS-type polymers [Popadek S.V. Once again, science and technology in the road sector [Engineering and Science in the Road Sector]. 2000. No.5. p. 9-10

5. Zolotarev V.A. Bitumens modified with polymers of type SBS: features of composition, structure and properties [Zolotarev V.A. Bitumens modified with SBS polymers: features of the com-position, structure and properties]. Kharkov. Kharkiv National Automobile and Highway University. 2003.

6. Horodecka R., Kalabinska M., Pilat J., Sybilski D. The influence of rubber-modified on asphalt concrete properties. The $5^{\text {th }}$ International Conference "Durable and safe Roads Pavements". Kielce, Poland, 11-12, May, 1999, p. 69-76.

7. Pilat J., Kalabinska M., Radziszewski P. Mieszankimineralnoasfaltowedodatkiemmialugumowego I wapna //MaterialyBudowlane. 2000.Nr.11.S.60-62. 
8. Gawel I., Kalabinska M., Pilat J. Asfaltydrogowe. WKiL., 2001,-255 p.

9. Gokhman L., Yumashev V. Durability - a sign of quality. Binding polymer-bituminous based on block copolymers of type SBS. (Industry standard OST 218.010-98) [L. Gokhman, V. Yumashev. Durability is a sign of quality. Polymer bitumen binders based on SBS block copolymers. (Industrial Standard 218.010-98)] Highways [Motorways]. 1998. № 8. Pp.12-14.

10. Recycled and rubberized SMA modified mixtures: A comparison between polymer modified bitumen and modified fibres Eskandarsefat, S., Dondi, G., Sangiorgi, C. 2019 Construction and Building Materials 202, c. 681-691.

11. Effect of freeze-thaw cycles on mechanical characteristics of bitumens and stone mastic asphalts Teltayev, B.B., Rossi, C.O., Izmailova, G.G., Amirbayev, E.D. 2019 Applied Sciences (Switzerland) 9(3), 458.

12. Electrically-conductive asphalt mastic: Temperature dependence and heating efficiency Arabzadeh, A., Ceylan, H., Kim, S., Gopalakrishnan, K., Mina, M. 2018, Materials and Design 157, c. 303-313.

13. Sugarcane bagasse fiber - An eco-friendly pavement of SMA Mansor, S., Zainuddin, N.I., Aziz, N.A., Razali, M., Joohari, M.I. 2018 AIP Conference Proceedings 2020,020032

14. Initial self-healing temperatures of asphalt mastics based on flow behavior index $\mathrm{Li}, \mathrm{C}$., Wu, S., Tao, G., Xiao, Y., 2018, Materials 11(6), 917.

15. Influence of fibres on rheological properties and toughness of bituminous binder Mohammed, M., Parry, T., Grenfell, J.J.R.A. 2018 Construction and Building Materials 163 , c. $901-911$.

16. Investigation of viscoelastoplastic behavior of asphalt mastic: Effects of shear strain rate and filler volume fraction Ma, X., Chen, H., Cao, G., Xing, M., Niu, D. 2019 Construction and Building Materials 200, c. 559-569.

17. Fatigue crack growth of a hot mix asphalt using digital image correlation Stewart, C.M., Garcia, E. 2019 International Journal of Fatigue 120, c. 254-266.

18. Rheological and interaction analysis of asphalt binder, mastic and mortar Chen, M., Javilla, B., Hong, W., Mo, L., Guo, M., 2019, Materials 12(1), 128.

19. Influence of hydrated lime on linear viscoelastic properties of bituminous mastics Phan, C.V., Di Benedetto, H., Sauzéat, C., Lesueur, D., Pouget, S., 2019 Mechanics of TimeDependent Materials

20. Investigation into the bond strength of bitumen-fibre mastic Mohammed, M., Parry, T., Thom, N., Grenfell, J. 2018 Construction and Building Materials, 190, c. 382-391.

21. Influence of rheological and physical bitumen properties on heat-induced self-healing of asphalt mastic beams Grossegger, D., Gomez-Meijide, B., Vansteenkiste, S., Garcia, A. 2018 Construction and Building Materials 182, c. 298-308. 